\title{
Farmland abandonment decreases the fire regulation capacity and the fire protection ecosystem service in mountain landscapes
}

\author{
Ângelo Sil ${ }^{\mathrm{a}, \mathrm{b}, \mathrm{c}, *}$, Paulo M. Fernandes ${ }^{\mathrm{c}}$, Ana Paula Rodrigues ${ }^{\mathrm{d}}$, Joaquim M. Alonso ${ }^{\mathrm{e}}$, \\ João P. Honrado ${ }^{\mathrm{a}, \mathrm{b}}$, Ajith Perera ${ }^{\mathrm{f}}$, João C. Azevedo ${ }^{\mathrm{g}}$

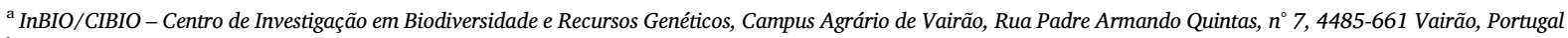 \\ ${ }^{\mathrm{b}}$ Faculdade de Ciências da Universidade do Porto, Rua Do Campo Alegre, S/N, Edifício FC4, 4169-007 Porto, Portugal \\ ${ }^{\mathrm{c}}$ Centro de Investigação e de Tecnologias Agro-Ambientais e Biológicas (CITAB), Universidade de Trás-os-Montes e Alto Douro, Apartado 1013, 5001-801, Portugal \\ ${ }^{\mathrm{d}}$ Instituto da Conservação da Natureza e Florestas (ICNF), Parque Florestal, 5300-000 Bragança, Portugal \\ ${ }^{\text {e }}$ Escola Superior Agrária, Instituto Politécnico de Viana do Castelo, Refóios do Lima, 4990-706 Ponte de Lima, Portugal \\ ${ }^{\mathrm{f}}$ Ontario Forest Research Institute, Ontario Ministry of Natural Resources, 1235 Queen Street E., Sault Ste. Marie, ON P6A 2E5, Canada \\ ${ }^{\mathrm{g}}$ Centro de Investigação de Montanha (CIMO), Instituto Politécnico de Bragança, Campus de Santa Apolónia, 5300-253 Bragança, Portugal
}

\section{A R T I C L E I N F O}

\section{Keywords:}

Ecosystem services

Farmland abandonment

Landscape change

Mediterranean mountains

Natural hazard regulation

Wildfire protection

\begin{abstract}
A B S T R A C T
This study explored and applied the concepts of Fire Regulation Capacity (FRC) and Fire Protection Ecosystem Service (FPES) in the assessment of the effects of landscape change in a mountain fire-prone landscape in Portugal. We adopted a modeling and simulation approach using BFOLDS-FRM with landscape data for years 1990 and 2006 (observed) and with three landscape scenarios for 2020. Proxy indicators for FRC (burned area and fire intensity) and for economic damage by fire (loss of provisioning ES) were used to establish trends in the supply and value of FPES. We found decreased FRC to restrain simulated fires burning over 100 ha from 1990 on and to regulate Very High and Extreme fire intensity levels, particularly under our 2020 scenario of Forest expansion. FPES is also expected to decrease, as indicated by higher fire-related damages, particularly if fuel hazard increases in the landscape. However, there were differences among scenarios, suggesting potential tradeoffs between FPES and the supply of provisioning ES. Planning and management in this and similar areas experiencing farmland abandonment must consider fire trends and patterns, since landscape change is a major driver affecting FRC and FPES, which may further be decreased by future climatic conditions.
\end{abstract}

\section{Introduction}

Fire is a widespread Earth process potentially occurring in more than $30 \%$ of the land worldwide (Chuvieco et al., 2008), caused either by natural factors or human-related ignitions (Pechony and Shindell, 2010), across many different ecosystem types (Krawchuk et al., 2009), and with multiple socio-ecological effects (Bond and Keane, 2017; Bowman et al., 2009, 2011). As a disturbance process of terrestrial ecosystems, fire intervenes in the regulation and the redistribution of energy and mass flows in the Earth system (McKenzie et al., 2011; Smith et al., 2016; Sugihara et al., 2004). For many biological communities and ecosystems, the occurrence of fire is crucial (Bond and Keane, 2017; Hutto, 2008; Keane et al., 2008). However, both climatic and anthropogenic drivers have been modifying the fire regime in both space and time (e.g. frequency, intensity, fire size, spread; Krebs et al.,
2010) on a global scale (Bowman et al., 2011; Pechony and Shindell, 2010), which may represent a higher risk to less fire-tolerant communities and less resilient ecosystems (Bond and Keane, 2017; Keane et al., 2008) and to human well-being (Bowman et al., 2009, 2011; de Guenni et al., 2005; Smith et al., 2016).

Fire regulation by ecosystems and landscapes is an ecological function that can mitigate the potential negative consequences of extreme fire events to a range of biological communities (Pettorelli et al., 2017), but also provide an important ecosystem service (ES) that benefits human safety, health and economies (de Groot et al., 2010; de Guenni et al., 2005; Haines-Young and Potschin, 2018; Pettorelli et al., 2017). The interaction of both abiotic and biotic factors, i.e. fuel, oxygen and a heat source, through the combustion process, allows fire to start (Byram, 1959), whereas fire spread is driven by the complex interaction between climate-weather, fuels, topography and ignition

\footnotetext{
* Corresponding author at: InBIO/CIBIO - Centro de Investigação em Biodiversidade e Recursos Genéticos, Campus Agrário de Vairão, Rua Padre Armando Quintas, $\mathrm{n}^{\circ}$ 7, 4485-661 Vairão, Portugal.

E-mail address: angelosil@cibio.up.pt (Â. Sil).
} 
source (e.g. Byram, 1959; Fernandes et al., 2016b; Rothermel, 1983; van Wagtendonk, 2004). Ecosystem properties (e.g. plant species composition, vertical and horizontal structure, biomass production) affect the characteristics of fuels available to burn (e.g. size, arrangement, load and moisture), the microclimatic conditions or the wind exposure, which largely contributes to define how fire will behave and the effects that it will produce. For instance, fire behavior descriptors (rate of spread, fireline intensity and crown fire potential) may vary depending on vertical and horizontal stand structure characteristics (Fernandes, 2009), and are major factors in determining fire severity (Fernandes et al., 2010); also, the degree at which fire intensity and fire rate of spread may be regulated depends on microclimate conditions (wind speed and fuel moisture) generated by different tree species (Pinto and Fernandes, 2014).

In addition, landscape patterns play an important role in regulating fire (Turner et al., 2001), particularly concerning landscape heterogeneity, since it can influence fire spread and intensity due to the abundance and the spatial pattern of fuels or the existence of fuel connectivity or barriers for fire spread (fuel breaks) in the landscape (Turner et al., 2013). For instance, growing landscape homogeneity increased fire proneness in Mediterranean ecosystems (Lloret et al., 2002); also, the effect of extreme weather on fire size was mitigated by increasing pyrodiversity on the landscape in Portugal (Fernandes et al., 2016b). On the other hand, landscape disturbances are able to regulate landscape patterns, which in turn affects ecological processes (e.g. net primary productivity or ecological succession), and disturbances regimes (Turner et al., 2013, 2001). For example, fire was able to change the spatial structure of different forest types in the landscape, which in turn caused a shift in fire regime (Pausas, 2006). Also, changes in land use and land cover (LULC) are expected to increase fire hazard due to the modification of landscape composition and configuration (e.g. Azevedo et al., 2011b; Martín-Martín et al., 2013).

The fire regulation capacity (FRC) concept (de Guenni et al., 2005) refers to the capability that both ecosystems and landscapes have in regulating spatiotemporal properties and characteristics of fire through the control of key factors that determine how fire behaves and the effects that may produce, which in turn are perceived as a beneficial ecosystem function, directly or indirectly, by a range of species (Pettorelli et al., 2017). The fire regulation capacity (FRC) can constitute a valuable function delivered by the ecological system to human well-being in terms of the maintenance of fires within acceptable impact thresholds, providing an important ecosystem service that may contribute to the protection against the harmful effects of fire (HainesYoung and Potschin, 2018).

Despite the importance of fire in most of the world (Krawchuk et al., 2009) and the socio-economic advantages resulting from fire regulation by ecosystems and landscapes, fire research from an ES point of view is scarce in the literature (de Guenni et al., 2005; Maes et al., 2011). This may be explained, at least partially, by the difficult identification of indicators to define and assess a fire-related service (Czúcz et al., 2018; Layke, 2009) due to the complexity of the processes involved in fire behavior and of their dynamics (e.g. McKenzie et al., 2011; Rothermel, 1983; van Wagtendonk, 2004), and also because catastrophic phenomena, such as wildfires, are sometimes addressed in the literature as ecosystem disservices (EDS) (Shackleton et al., 2016; Vaz et al., 2017). Although some efforts have been made to identify potential indicators (Maes et al., 2011; Pettorelli et al., 2017), the inclusion of wildfires in ES-based (or EDS-based) assessment frameworks remains limited. Exceptions include case studies using fire metrics in ES assessment (Azevedo et al., 2011a; Halofsky et al., 2017; Madureira et al., 2013), or econometric approaches to assess the resulting service (Bernués et al., 2014; Madureira et al., 2013; Ninan and Kontoleon, 2016; Parthum et al., 2017; Román et al., 2013).

According to standardized ES typologies, this service is part of the regulating ES category subset, which is generally referred to as natural hazard mitigation (Alcamo et al., 2003; de Groot et al., 2010; MEA,
2005). Several definitions for the fire-regulating ES provided by ecosystems and landscapes can be found in the literature (e.g. Azevedo et al., 2011a; Halofsky et al., 2017; Madureira et al., 2013; Parthum et al., 2017). However, the latest v5.1 version of CICES (Haines-Young and Potschin, 2018) defines more clearly the service by including a new class described as "Fire protection" ES (FPES) within the group 'Regulation of baseline flows and extreme events', which recognizes the ecological and anthropic dimensions that underlie the service, i.e., the role of ecological features and the contribution of their outcomes (e.g. the reduction of fire incidence, intensity or rate of spread) to human protection, by mitigating or preventing damages (costs) caused by fires to humans (e.g. human health and safety) and their livelihoods (e.g. the usage of natural resources by people).

Modifications in ecosystems and landscapes are likely to change FRC and increase the vulnerability of the human system (e.g. threats to human lives and health, property damage, loss of habitats, soil erosion, loss of productivity, and ultimately land degradation) (de Guenni et al., 2005). Important LULC changes that took place across Europe (Kuemmerle et al., 2016), mainly driven by rural depopulation and land abandonment (Weissteiner et al., 2011), particularly in mountains (e.g. Honrado et al., 2017; McDonald et al., 2000; Moreira et al., 2008; Poyatos et al., 2003) are expected to increase fire hazard if landscape heterogeneity decrease and/or the amount of contiguous fuel loads available to burn increase (e.g. Benayas et al., 2007; Moreira et al., 2011). In addition, the Mediterranean climate characterized by extended droughts combined with high temperatures, is also a key fire driver that may be aggravated by future extreme weather conditions resulting from climate change (Dubrovský et al., 2014), further increasing the risk of wildfires (e.g. Moriondo et al., 2006; Pereira et al., 2013).

Between 1990 and 2016 there were, on average, nearly 76,000 fires burning more than 450 kha per year in Europe (San-Miguel-Ayanz et al., 2016). Mediterranean countries, including mainland Portugal, accounted for more than $90 \%$ of the total burned area and more than $75 \%$ of all wildfires occurring annually (San-Miguel-Ayanz et al., 2016), where $95 \%$ were human-driven ignitions, which essentially are driven by socio-economic and cultural factors (Ganteaume et al., 2013). Wildfires impact annually $3 \%$ of the Portuguese wildland, leading to socioeconomic damages that average 276.6 million $€$ per year (Mateus and Fernandes, 2014; Rego et al., 2013), and the loss of human lives, as occurred in 2017, where fires were particularly disastrous, killing 113 people and burning nearly 0.5 million ha (ICNF, 2017). The management of wildfire hazard is therefore crucial for the protection of human communities and their livelihoods. Anticipating the effects of future climate and land use changes on the fire regulation capacity (FRC) and the resulting fire protection ES (FPES) is therefore paramount to design and implement fire-smart management strategies (Fernandes, 2013).

This study was developed in a fire-prone mountain region undergoing land abandonment and aimed to (i) clarify and apply the concepts of Fire Regulation Capacity (FRC) and Fire Protection Ecosystem Service (FPES), (ii) assess changes in FRC driven by landscape change, and (iii) assess how those changes affect the potential supply of FPES, i.e. the benefits to humans and their livelihoods deriving from landscape regulation of harmful wildfire impacts. We applied a modeling and simulation approach to identify landscape pathways with negative effects on FRC (and FPES) under extreme weather conditions, in order to improve the management of fire-prone landscapes. Our research workflow was based on the following questions sequentially applied to the study region: (i) how does landscape change affect FRC?; (ii) what is the impact of changes in the fire regulation capacity on the supply of FPES?; and (iii) what is the economic value of FPES, how did it change over time and how will it potentially change in the future? 
(a)

(b)

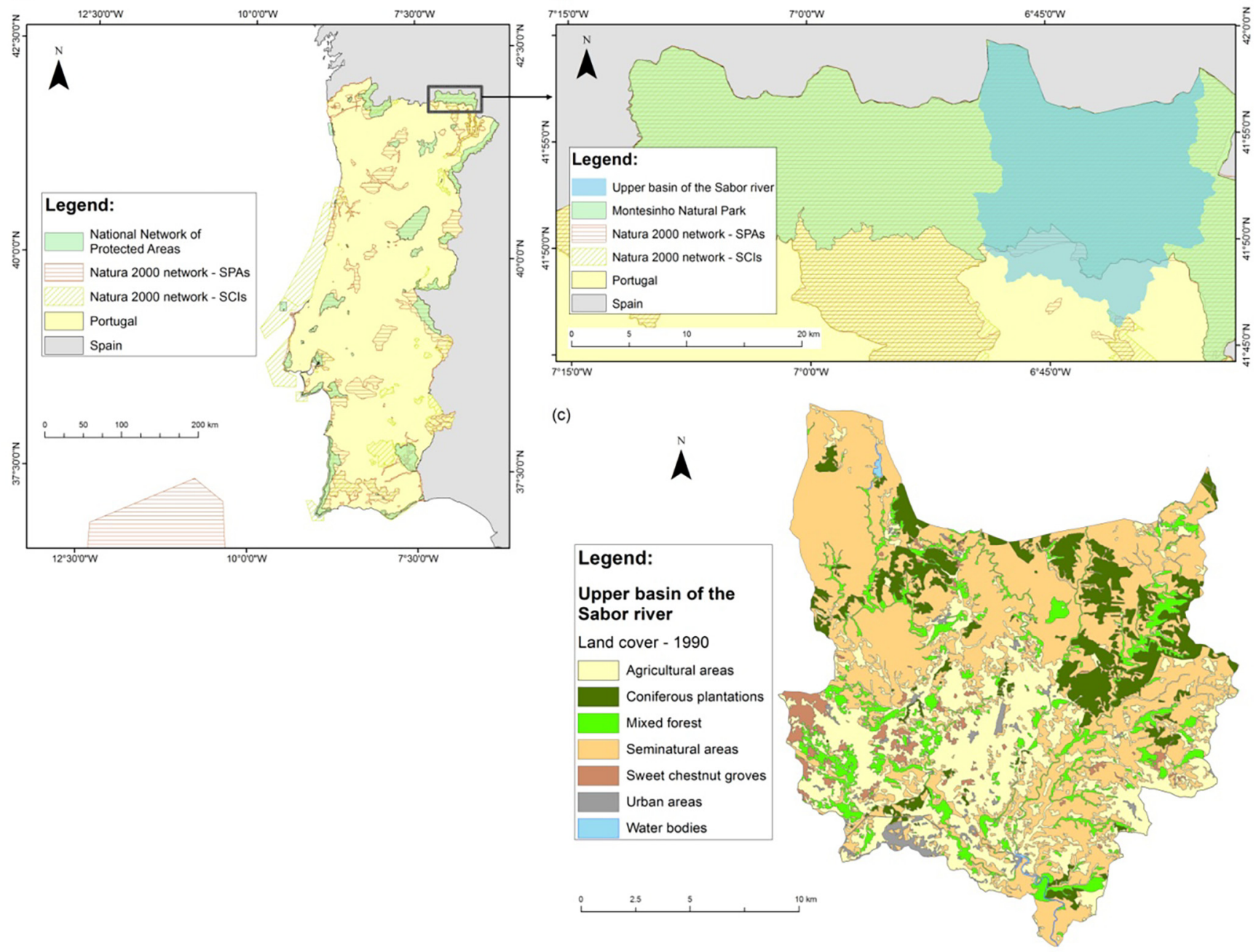

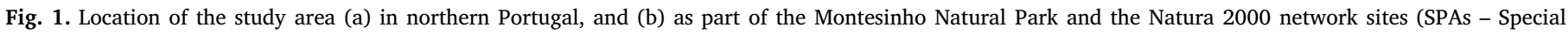
Protection Areas, and SCIs - Sites of Community Interest); c) Land cover map with indication of the major land cover types in 1990.

\section{Methods}

\subsection{Study area}

The study was conducted in the upper basin of the Sabor river, a 30,650 ha mountain area in northern Portugal. The area is included in the Montesinho Natural Park and in the Natura 2000 site 'MontesinhoNogueira' (Fig. 1). Different topographic, bioclimatic and geological conditions combined with traditional land management promote a diversity of LULC types throughout the landscape, in which semi-natural vegetation and, more recently, forests are predominant (Azevedo et al., 2011a,b; Carvalho-Santos et al., 2017; Sil et al., 2017, 2016).

Rural depopulation and socioeconomic changes that have taken place in the region over several decades produced widespread abandonment of marginal agricultural land. Mountain afforestation programs in the mid-20th century, and the recent conversion of annual crops to permanent sweet chestnut groves, also contributed to the strong changes observed in this landscape (Azevedo et al., 2011a,b). Consequently, the potential supply of several ES has been enhanced in this region (Sil et al., 2017, 2016). On the other hand, the number of wildfires and the burned area increased from 1990 to the mid-2000's, with a small decline in the last decade (ICNF, 2015). Several studies conducted locally (Azevedo et al., 2013, 2011a,b; Magalhães et al., 2017; Monteiro 2011; Moreira et al., 2008; Rachdi, 2016; Silva et al., 2011) suggest that LULC changes, topography, and vegetation type and structure are relevant factors that affect fire behavior in the area.

\subsection{Approach and research framework}

We assumed that Fire Regulation Capacity (FRC) is an ecosystem function (Pettorelli et al., 2017) defined here as the capability of ecosystems and landscapes to regulate spatiotemporal attributes of fire regimes through the control of factors affecting fire behavior and impacts. We also assumed that FRC enables the supply of the Fire Protection Ecosystem Service (FPES) whenever it contributes to prevent harmful impacts of wildfires on humans and their livelihoods, and promotes the receipt of benefits (de Guenni et al., 2005; Haines-Young and Potschin 2018; Pettorelli et al., 2017).

Therefore, the FPES was considered here as the contribution of landscape FRC to prevent losses of other ES supplied (i.e. benefits) in the study area caused by fire, whose value was derived from the assessment of the potential supply of provisioning ES and the direct damages incurred from fire in monetary terms, following a production function-based approach (Pascual et al., 2010). We assumed that the FPES value estimated represents only partially the potential value that this ES in the study area.

We assessed FRC based on two output metrics of simulated fire behavior (fire extent and fire intensity), considered as proxies (Pettorelli et al., 2017). This was applied in a context of landscape change based on LULC data in the study area for 1990 and 2006, as well 
as for three landscape scenarios for 2020. We assumed that increased burned area and fire intensity are indicative of decreased FRC (de Guenni et al., 2005; Pettorelli et al., 2017). We also assumed that decreasing FRC is harmful for humans since it increases the negative impacts of wildfires on well-being (de Guenni et al., 2005; HainesYoung and Potschin 2018).

We then computed FPES based on the economic impact (damage) of simulated fires on the value of three provisioning ES important for the local economy: wild mushrooms, firewood, and timber production. It was expressed as a function of the potential economic value of the three provisioning ES and of the value of these ES that are lost in simulated fire events (damage). Differences in fire-caused damage between specific dates and landscape scenarios indicate economic trade-offs between FPES and provisioning ES under different pathways of landscape change in the study area (de Groot et al., 2010).

\subsection{Fire simulations}

\subsubsection{Experimental setup}

The Boreal Forest Landscape Dynamics Simulator - Fire Regime Module (BFOLDS-FRM) (Perera et al., 2008, 2014), specifically the LANDIS-II extension (Scheller et al., 2007) was used to simulate fires across the landscape in 1990, 2006, and 2020 (3 scenarios). BFOLDSFRM is a spatially explicit process-based model that simulates fire growth using information on land cover, weather and topography. We ran all simulations under extreme fire weather conditions, to consider the worst-case scenario of potential fire behavior and because burned area is strongly associated with dry and windy summer conditions in Portugal and in the Mediterranean region (e.g. Pereira et al., 2013; Turco et al., 2017). We set each simulation to run for a maximum of four days, based on available data on consecutive extreme fire weather days for the area. We assumed constant fire weather severity, with fire extinction either at the end of the simulation, when fire reached nonburnable land cover classes, or when it reached the limits of the study area. Fuel characteristics used in the simulations were maintained constant over time, i.e. we assumed no vegetation growth. Also, the location of the ignition points ( $n=30$ per date/scenario) was kept constant for all the simulations. Under these assumptions, fire behavior analysis over time (1990-2020) was a function of changes in landscape composition and configuration. BFOLDS simulations $(n=150)$ ran independently to avoid conflicts among fire ignitions in the landscape.

\subsubsection{Fire ignition points}

We simulated fires across the landscape from 30 ignition points per date/scenario that were kept constant for all the simulations (Fig. 2). GIS functions were used to randomly distribute these points over the landscape, excluding agriculture due to its relatively low fire proneness (Barros and Pereira, 2014; Carmo et al., 2011) and non-burnable urban areas and water bodies. Although the number of fires in European Mediterranean countries may vary in space and time according to changes in their socioeconomic context (Ganteaume et al., 2013), we assumed that those factors were constant over time and did not influence neither the location nor the number of fires simulated. In addition, we tested the effect of the sample size (i.e. the number of fire points used in the simulations) in each date/scenario, which indicated that using 30 points in the sample would be enough to capture the variability of the output variables, and also that increasing the sample size to more than 30 points would not produce significant changes in the results since the variance stabilized around $n=30$.

\subsubsection{Simulation scenarios}

Besides the available spatial LULC databases for years 1990 and 2006, we used three alternative future (2020) landscape scenarios that were previously established (Sil et al., 2017). Scenarios in the present study aimed to explore how different pathways of landscape evolution may affect FRC and FPES in the future, considering the current trend of the landscape towards abandonment as the baseline. We built the scenarios based on the major transition patterns observed for two parishes within the study area, identified after the analysis of the probability transition matrices (from year 1992 to 2006) available in the studies of Azevedo et al. (2011b) and Pinheiro et al. (2014).

Therefore, we have considered the following alternative landscape scenarios for 2020: "Rural abandonment" intends to simulate the abandonment of the landscape at a similar rate that has occurred in the recent past (i.e. from 1990 to 2006), reflecting a moderate increase of forest and semi-natural areas on abandoned agricultural land; "Forest expansion" intends to simulate a substantial increase of forest areas in the landscape either by afforestation or natural regeneration that may convert abandoned agricultural fields and semi-natural areas into forest plantations and/or natural forests; and "Shrubland expansion" intends to simulate the increase of semi-natural areas in the landscape due to the encroachment of shrubs in abandoned agricultural fields and forest areas affected by fires. Table 1 summarizes the landscape transitions occurred between 1990 and 2006, and 1990 and 2020 (scenarios) for the major cover types in the study area. The observed and the simulated landscape raster datasets were prepared at a $25-\mathrm{m}$ spatial resolution based on the corresponding land cover maps.

\subsubsection{Simulation input data}

Fuel types. Burnable LULC classes were aggregated into four major cover types (coniferous forest, mixed forest, sweet chestnut agroforestry systems, and semi-natural vegetation). Two original fuel types (C6, M2 25\% Conifer) from the Canadian Fire Behavior Prediction System (CFBP) (Forestry Canada Fire Danger Group, 1992) available in BFOLDS-FRM were used in the simulations, while CFBP models O1a and O1b were customized to best fit the vegetation types in the study area. The description of CFBP fuel types, their adaptation and the parameters for each fuel type used in the simulations are summarized in Supplementary Material A.

Weather data. Four consecutive days with extreme fire weather (FWI > 55) (Viegas et al., 2004) were selected from the closest (Bragança) weather station database (Supplementary Material B). The Canadian Forest Fire Weather Index System codes (FFMC, DMC, BUI and FWI) were computed from daily temperature, relative humidity, and wind speed measured at noon, and 24-hour cumulative rainfall, collected from the Bragança weather station dataset. Due to lack of wind direction data, required by BFOLDS, the dominant east to west wildfire orientation in the region (Barros et al., 2012) was assumed as the wind direction common to all simulations.

Topography. Terrain spatial data (latitude and longitude, slope, aspect) was computed at 25-m spatial resolution using GIS functions based on the Digital Elevation Model (DEM) for Portugal (Gonçalves and Morgado, 2008).

\subsubsection{BFOLDS-FRM scenario file}

BFOLDS-FRM parameters were customized in order to fit the model to the study area conditions. DMC threshold values were adjusted based on expert knowledge and wildfire data, respectively, 5 for ignition (default value $=20$ ), and 12 for sustained fire spread (default value $=20$ ). All other parameters were set at their default values.

\subsection{Estimates and value of provisioning ES}

The economic value of FPES was assessed based on the evaluation of impacts of fire on the supply and the market price of three provisioning ES valued in the region, namely wild mushrooms, firewood and timber production. Data available from previous research on the assessment of ecosystem services indicators and trends within the study area (Rodrigues, 2015; Sil et al., 2016) supplied the data used in the present work. Table 2 summarizes the approaches used to estimate the selected provisioning ES and their value. 


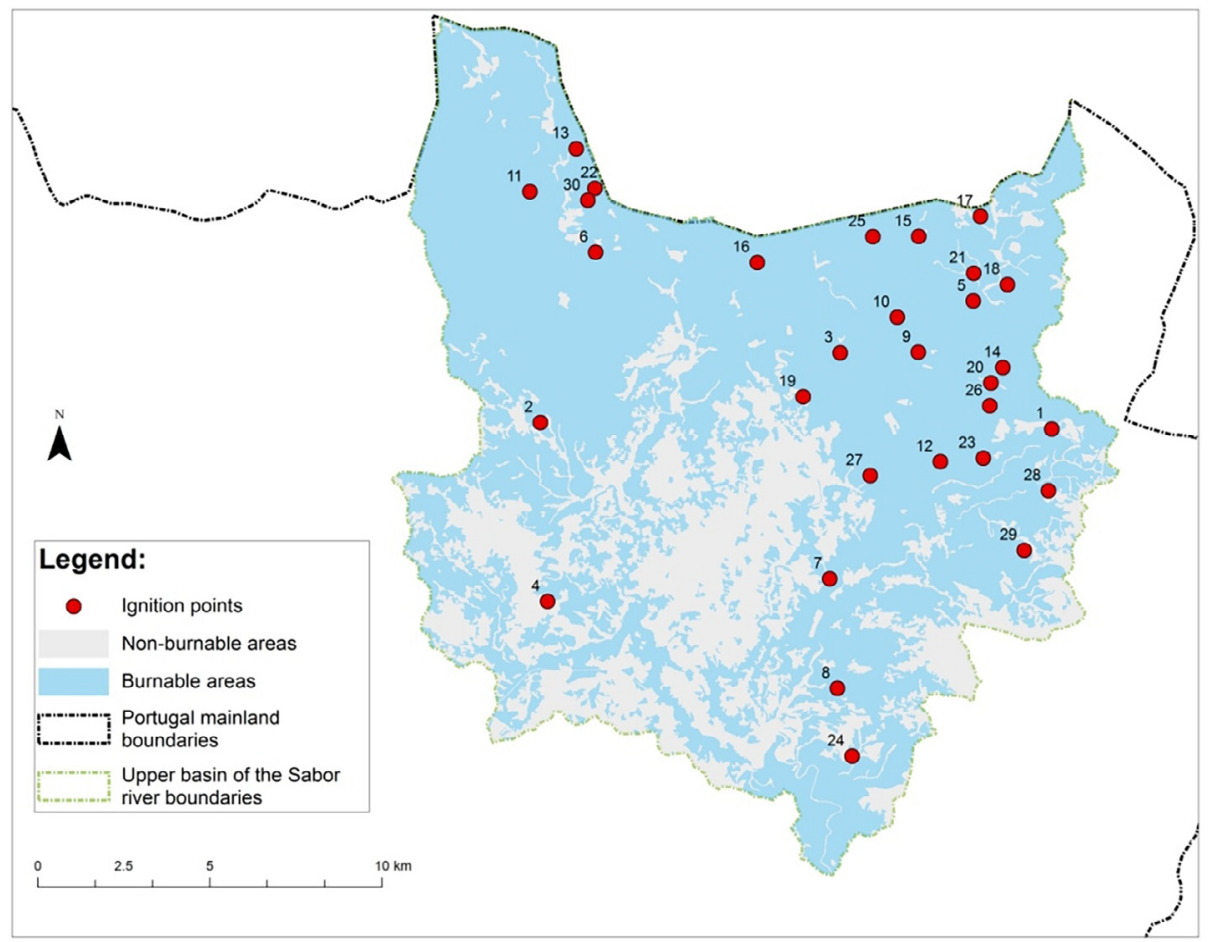

Fig. 2. Distribution of the 30 ignition points for fire behavior simulations in the study area.

Table 1

Landscape transitions (\%) occurred between observed (1990-2006) and simulated scenarios (1990-2020) for the major cover types in the upper basin of the Sabor River.

\begin{tabular}{|c|c|c|c|c|c|c|}
\hline \multicolumn{2}{|c|}{ Transition } & \multicolumn{5}{|l|}{ Cover type } \\
\hline From & To & Agriculture & Mixed forest & Coniferous forest & Sweet chestnut agroforestry & Semi-natural vegetation \\
\hline \multirow[t]{4}{*}{1990} & 2006 & -13.8 & 45.6 & 3.9 & 16.0 & -3.3 \\
\hline & 2020 - Rural abandonment & -35.3 & 56.9 & 14.8 & 26.6 & 3.2 \\
\hline & 2020 - Forest expansion & -21.4 & 117.3 & 61.1 & 74.6 & -28.8 \\
\hline & 2020- Shrubland expansion & -23.2 & 15.5 & -20.7 & 11.1 & 13.0 \\
\hline
\end{tabular}

\subsection{Data analysis}

FRC was analyzed based on burned area and fire intensity, assuming as baseline scenario the year of 1990 to coincide with the earliest available description of the landscape (see Fig. 1c). We adopted as reference the number of fires with a burned area $\geq 100$ ha [i.e. Large Fires ( $\geq 100$ ha), the official size threshold (ICNF, 2017); and Extremely Large Fires ( $>2500$ ha; Fernandes et al., 2016a)], and the average burned area at Very High and Extreme fire intensity in 1990. The fire intensity classification expresses fire suppression difficulty (Alexander and Lanoville, 1989): Low ( $<500 \mathrm{~kW} / \mathrm{m})$, Moderate $(500-2000 \mathrm{~kW} /$ $\mathrm{m})$, Very High $(2000-10,000 \mathrm{~kW} / \mathrm{m})$ and Extreme $(>10,000 \mathrm{~kW} / \mathrm{m})$. We then assessed the same metrics for 2006 and for each LULC scenario in 2020.

Differences among dates and scenarios were statistically analyzed using IBM SPSS Statistics for Windows, Version 20.0 (IBM Corp, 2011), applying nonparametric statistics, namely Cochran's $Q$ test followed by Dunn's pairwise tests for $\alpha=0.05$ for comparisons of fire size distribution; and Kruskal-Wallis $\mathrm{H}$ test followed by a mean rank multiple comparison for $\alpha=0.05$, using Dunn's pairwise tests with Bonferroni error correction, for comparisons of overall average burned area or overall average fire intensity distributions, and burned area per fire

Table 2

Summary of approaches and data sources used in the biophysical and economic valuation of the selected provisioning ES to assess FPES.

\begin{tabular}{|c|c|c|}
\hline Ecosystem service & Biophysical valuation & Economic valuation \\
\hline Wild mushrooms & $\begin{array}{l}\text { Estimates of the production of potential supply of mushrooms in each habitat } \\
\text { occurring in the study area for each of the species known to be collected for } \\
\text { home consumption or commercial sale in the region (Garcia et al., 2006) }\end{array}$ & $\begin{array}{l}\text { Average market prices reported for the Northeast of Portugal (Garcia et al., } \\
\text { 2006) }\end{array}$ \\
\hline Firewood & $\begin{array}{l}\text { Estimates of the living aboveground biomass of pure hardwood forest in the } \\
\text { area using a production table (Carvalho, 2000) for Quercus pyrenaica in the } \\
\text { region }\end{array}$ & $\begin{array}{l}\text { Average market price of firewood in the region, assumed to be } 100 € / \mathrm{Mg} \\
\text { (based on local market transactions) }\end{array}$ \\
\hline Timber & $\begin{array}{l}\text { Data on the volume of softwood harvested in two forest perimeters within the } \\
\text { study area, and estimates of the harvestable volume of softwood available in } \\
\text { the area through modelling using a regional growth and yield model for } P \text {. } \\
\text { pinaster - (FlorNExT; Peréz-Rodrígues et al., 2015) }\end{array}$ & $\begin{array}{l}\text { Average timber market price per diameter class (Duro, 2008). Softwood } \\
\text { stands younger than } 20 \text { years and small in diameter }(<14 \mathrm{~cm} \text { ) were } \\
\text { considered as without market value (Rodrigues, 2015; Sil et al., 2016) }\end{array}$ \\
\hline
\end{tabular}


intensity distributions (Supplementary Material C).

FPES in each date/scenario was calculated as the difference between the value of the potential (maximum) supply of mushrooms, firewood and timber, and the value of these provisioning ES lost by the simulated fires. The latter was obtained by multiplying the average burned area per land cover type by the biophysical and economic estimates of each provisioning service made for years 1990, 2006, and 2020 (3 scenarios). Since FPES in the landscape changed over time, it is presented also as the percentage of the maximum ES that remained after fire. We assumed that burned land cover types were totally damaged by fire, representing complete loss of the provisioning ES supply within those areas.

\section{Results}

\subsection{Landscape fire regulation capacity}

The LULC changes observed between 1990 and 2006 increased slightly the simulated total and average burned area. This trend was also obtained for two 2020 landscape scenarios (Rural abandonment and, especially, Forest expansion, with significantly different values ( $p=0.016$ ) from those of all other dates/scenarios), whereas a decrease was observed under the Shrubland expansion scenario (Fig. 3a).

There was also a small increase of the average fire intensity between 1990 and 2006, but a more substantial increase was found for the 2020 Forest expansion scenario, while the two other scenarios showed a decrease (Fig. 3b). Average fire intensity was significantly different $(p=0.000)$ among scenarios and dates.

The number of large fires ( $\geq 100$ ha) may have increased slightly as
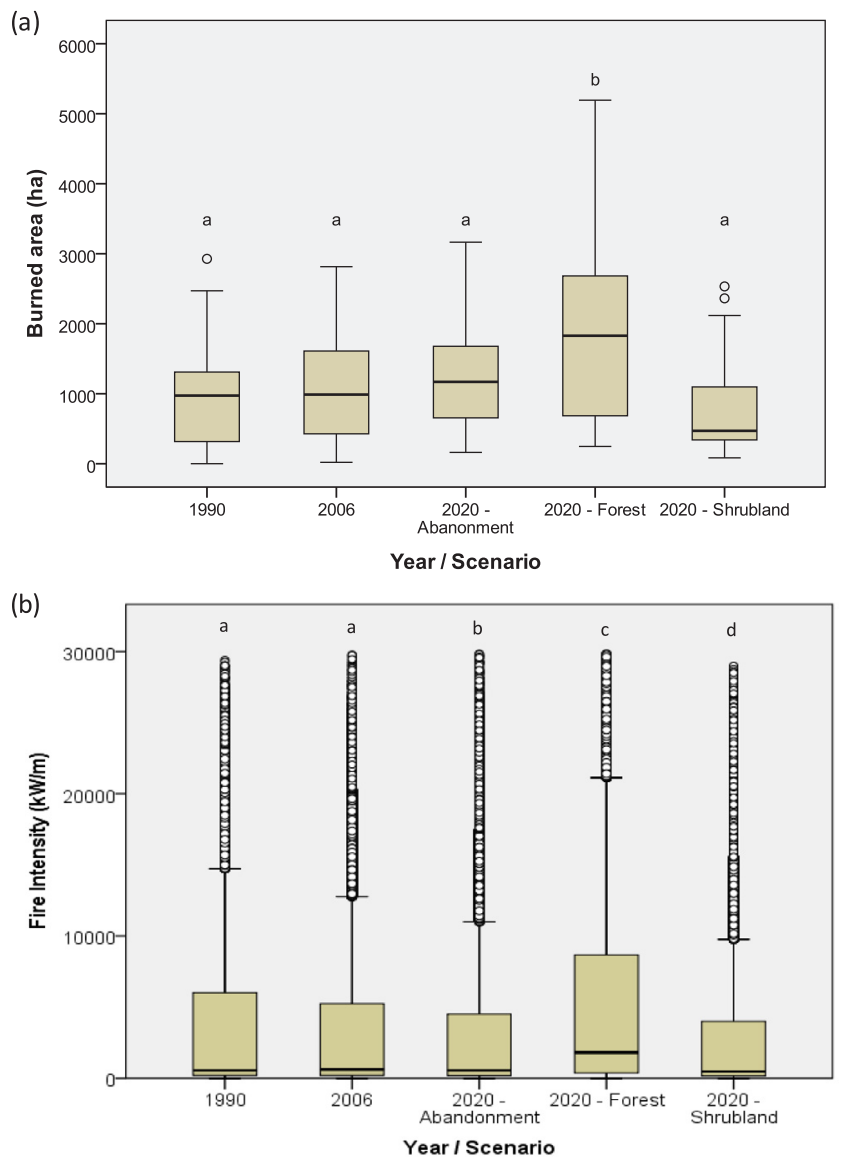

Fig. 3. Burned area (a) and fire intensity (b) per date and scenario based on 30 simulated fires. Median, quartiles and outlier values are shown. Distributions with different letters are significantly different.

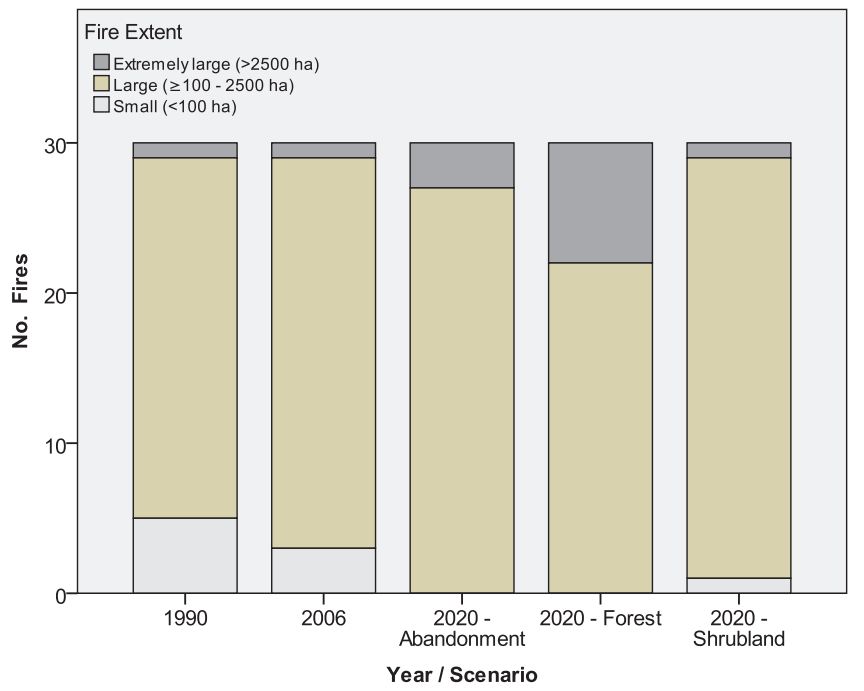

Fig. 4. Distribution of fires per size class in 1990, 2006 and 2020 scenarios based on 30 simulated fires.

a result of the observed landscape changes (1990-2006), but a significant increase $(p=0.019)$ was found between the 1990 baseline and the Rural abandonment and Forest expansion scenarios for 2020 (Fig. 4). Also, the number of extremely large fires ( $>2500$ ha) increased in these same 2020 scenarios, but especially in the latter, while under the Shrubland expansion scenario large fires were more frequent than extremely large fires (Fig. 4).

The distribution of burned area per fire intensity class showed a similar pattern among dates and scenarios. The Low fire intensity class accounted for the highest burned areas, usually followed by the Very High, Moderate and Extreme classes (Fig. 5). Between 1990 and 2006, despite landscape changes resulting in a general increase of fire intensity, there was an areal decrease of Very High and Extreme fire intensity (Fig. 5). Compared with the baseline, future fire intensity generally increased under the Forest expansion scenario, and decreased under the Rural abandonment and Shrubland expansion scenarios (Fig. 5). However, areas burned at Very High fire intensity increased for both Rural abandonment and Forest expansion scenarios, whereas areas burned at Extreme fire intensity increased significantly $(p=0.024)$ only in the latter scenario (Fig. 5). This is mainly a result of the higher forest cover in these two scenarios, but especially of coniferous plantations under the Forest expansion scenario (Fig. 6).

\subsection{Fire protection ecosystem service}

The estimated economic losses of the selected provisioning ES due to fire damage increased slightly between 1990 and 2006 and are predicted to grow further under the several future landscape scenarios (Fig. 7). This growth is a consequence of increasing both fire size and the supply and value of provisioning ES. Expressing FPES as a proportion of the potential (maximum) economic value of the provisioning ES (i.e. if not impacted by fire), to control the effect of the growing supply and value of the provisioning ES, we predicted a decrease in the supply of FPES from 1990 (90.9\%) to $2006(86.8 \%)$ as well as from 1990 to 2020 in the Abandonment (87.1\%) and Forest expansion (80.8\%) scenarios. In the latter scenario, losses account for as much as $6.5 \mathrm{M} €$ of the potential value of provisioning ES (33.9 M€). FPES in the Shrubland expansion scenario $(89.9 \%)$ is close to the level observed in 1990 although absolute losses due to fire in this 2020 scenario are much higher (2.36 M€).

The Forest expansion scenario yields the highest potential income in the study area in 2020 but, at the same time, the highest potential losses caused by fire (Fig. 8). The Shrubland expansion scenario holds the 

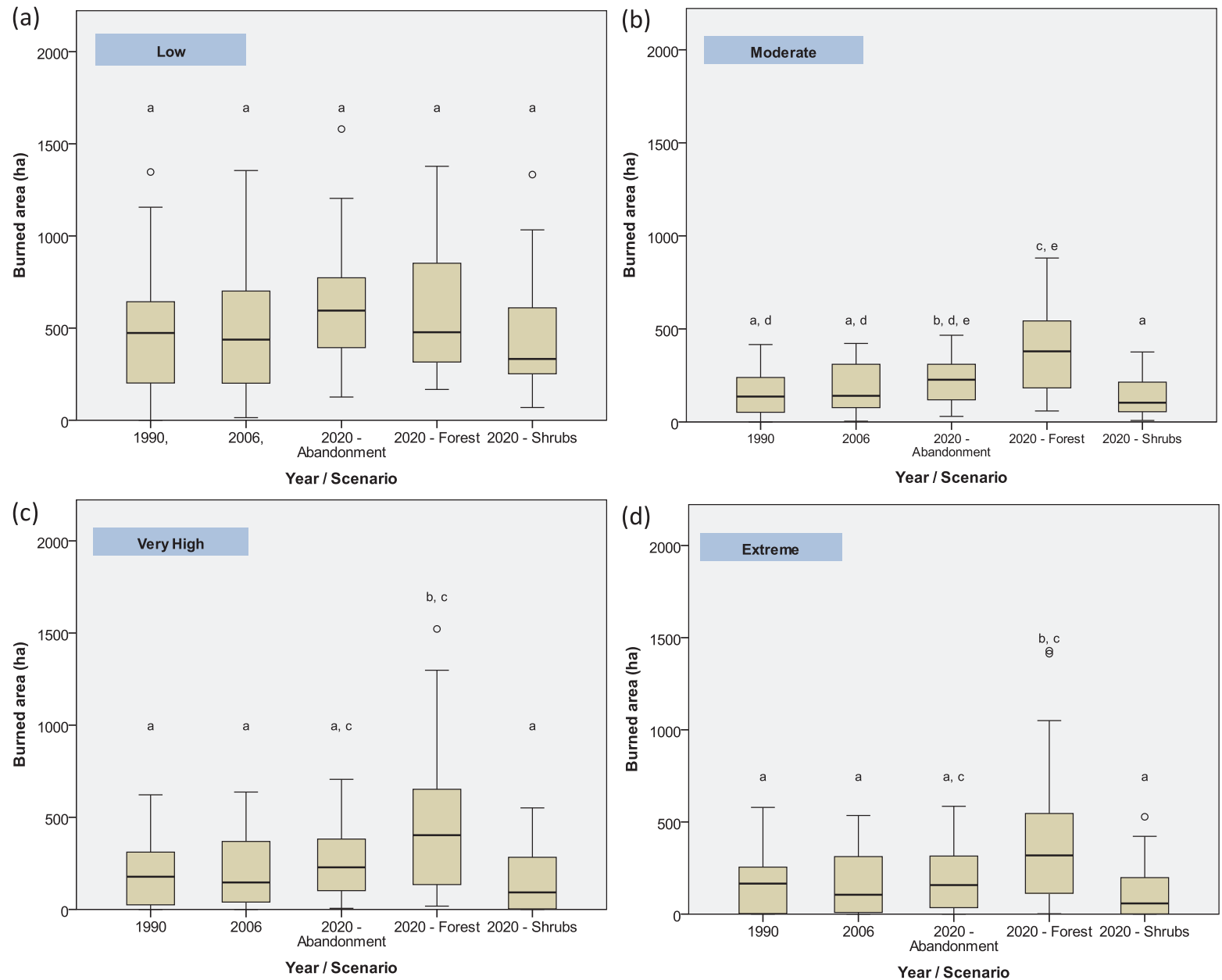

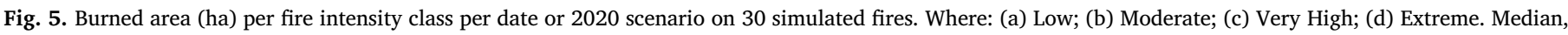
quartiles and outlier values are shown. Distributions with different letters are significantly different.

lowest potential losses but also the lowest potential income, whereas the Rural abandonment scenario presents higher levels of potential income derived from provisioning ES supply and moderate potential losses caused by fire (Fig. 8).

\section{Discussion}

\subsection{Trends in fire regulation capacity}

The decrease of agricultural areas observed from 1990 to 2006 $(-14 \%)$ due to abandonment and their replacement by more flammable land cover types, led to changes in landscape structure, more pronounced in the simulated alternative landscape scenarios. The Rural abandonment scenario represents a loss of $35 \%$ of agricultural land in this period, while the Forest expansion and the Shrubland expansion scenarios represent losses of this LULC class of 21 and 23\%, respectively. Agricultural areas may act as fuel breaks and their replacement affects the distribution of fuels in the landscape, increasing both fuel horizontal continuity and fuel availability. These changes affected fire behavior (Fig. 3) and the capacity of the landscape to regulate fire (Figs. 4-6).

Increasing number of fires $\geq 100$ ha between 1990 and 2006 and also from 2006 to 2020 (all scenarios) indicates a decrease in the Fire Regulation Capacity of the Sabor River's landscape (Fig. 4). For the particular case of the 2020 scenarios Forest expansion and Rural abandonment, it is the number of fires larger than 2500 ha that indicate a considerable decrease in FRC in the landscape (Fig. 4). In addition to size, fire intensity also tended to increase between 1990 and 2006, despite the capacity of the landscape to mitigate Very High and Extreme intensity events increased slightly, but not significantly, during this period (Fig. 5). Among 2020 scenarios, although fires tended to become larger only the Forest expansion landscape showed a significant reduction of the capacity to regulate Very High and Extreme intensity events, whereas the remaining scenarios showed that extremely intense fires may be mitigated, but not significantly (Fig. 5).

The decrease of areas burned at Very High and Extreme fire intensity in 2006 and in the 2020 Shrubland expansion scenario is partially explained by the reduction of burned conifer stands, which did not occur in the 2020 Forest expansion and the Rural abandonment scenarios, despite the latter having an increase of sweet chestnut groves and mixed forest in the landscape, which contributed to balancing low and high fuel hazard areas (Figs. 5 and 6). Contrarily, the Forest expansion scenario increased in fire intensity in general and in the frequency of higher fire intensity classes. This pattern is partially explained by the sizeable expansion of forest particularly at the expense of semi-natural areas, resulting in more burned forest, particularly conifers, and in a higher fraction of area burned at Very High and Extreme fire intensity levels (Figs. 5 and 6). Hence, in this scenario, the landscape capacity to restrain extreme fire intensity events is low, suggesting that a higher percentage of the area will eventually experience high damage.

Our results agree with other studies in Mediterranean Europe reporting similar trends in land abandonment (mainly of farmland) leading to natural vegetation encroachment or afforestation, increasing 

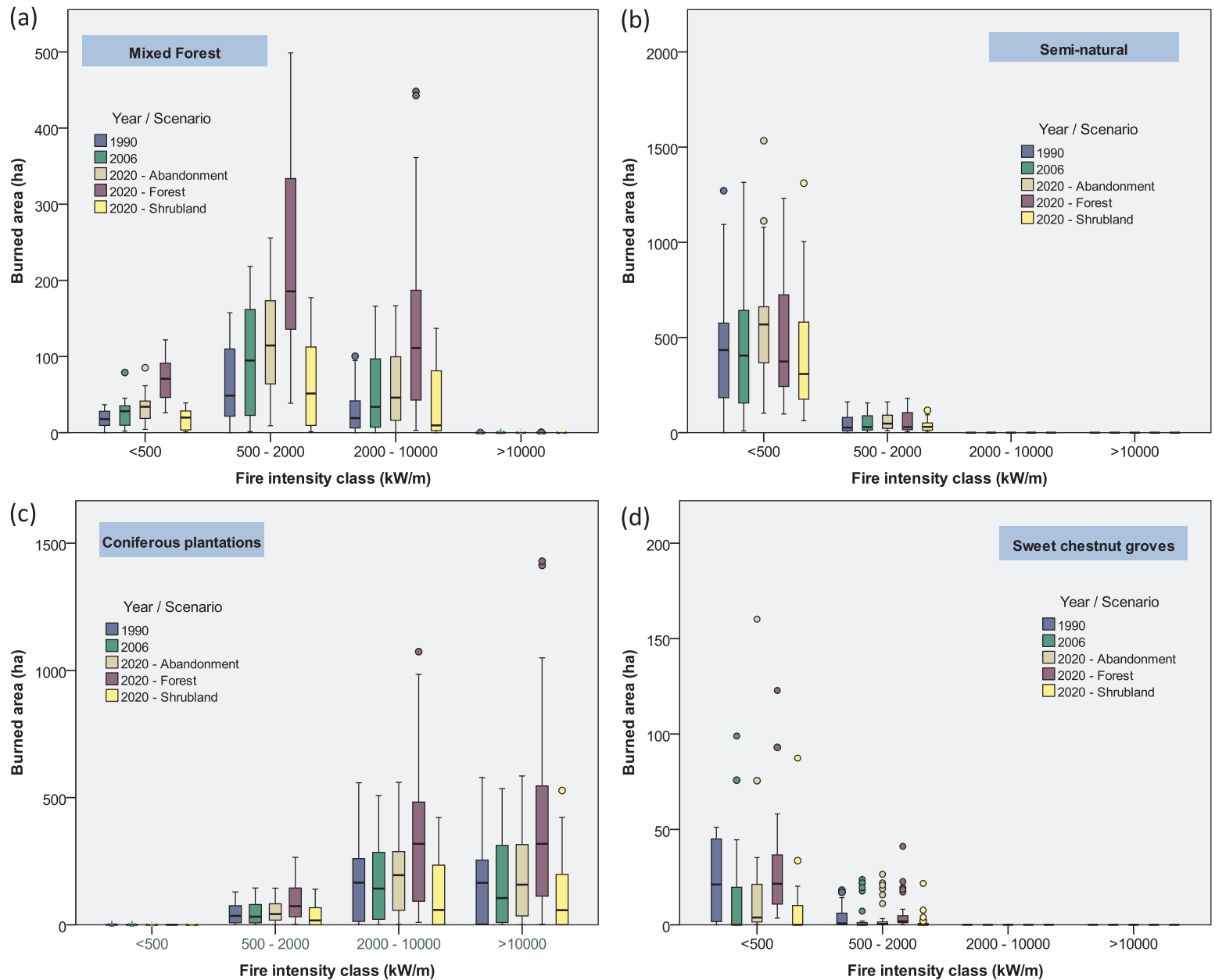

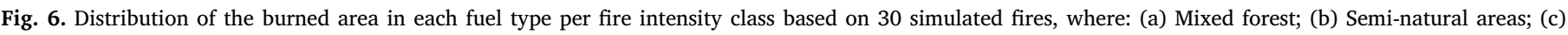
Coniferous plantations; (d) Sweet chestnut groves. Median, quartiles and outlier values are shown.

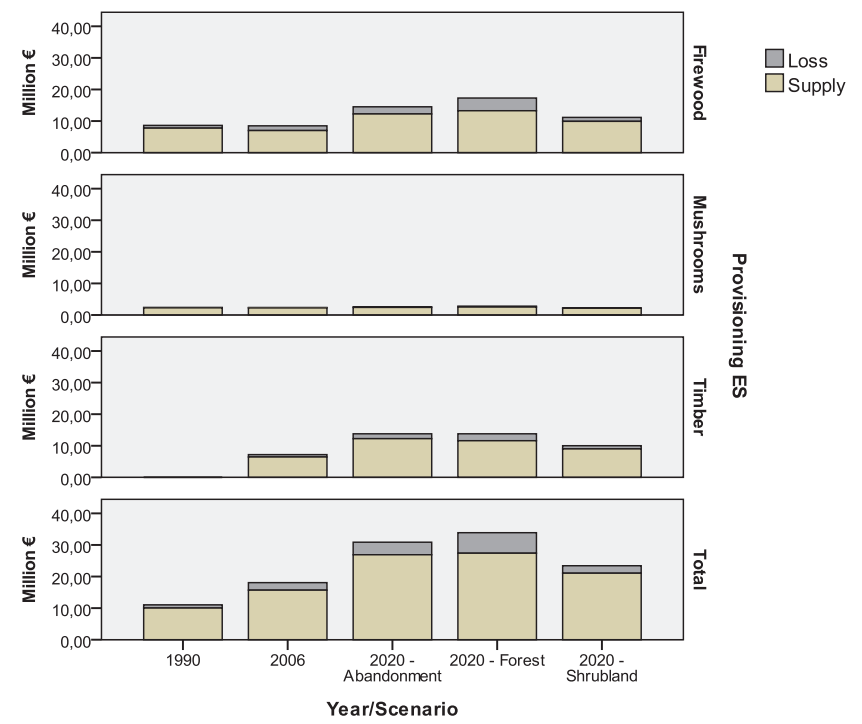

Fig. 7. Estimated economic value (million $€$ ) of the selected provisioning ecosystem services in the study area. The columns represent the total economic value, including the estimated losses due to fires and the remaining potential supply per date and scenario. homogeneity and fuel contiguity in the landscape and producing changes in fire behavior patterns (Azevedo et al., 2011a,b; Benayas et al., 2007; Duguy et al., 2007; Fernandes et al., 2016b, 2014; MartínMartín et al., 2013; Montiel and Galiana-Martín, 2016; Moreira et al., 2011; Pausas and Fernández-Muñoz, 2012; Vega-García and Chuvieco, 2006; Viedma et al., 2009). Our results follow the generic trends for Mediterranean Europe, where changes in landscape composition are major drivers of change in fire behavior (Moreira et al., 2011). Our results are also in line with Fernandes (2009) and Fernandes et al. (2014, 2010), that describe similar trends regarding changes in fire hazard due to changes in fuel composition and structure, as well as with Azevedo et al. (2011a,b), that reported an increase of extreme fire danger after expansion of shrub and forestland replacing farmland within or near the studied watershed.

However, our results differ slightly from some of the other studies mentioned above (e.g. Azevedo et al., 2011b; Duguy et al., 2007; Moreira et al., 2011) regarding higher fire proneness of shrubland when compared to forest or agricultural areas, due to the higher rate of spread and fire intensity exhibited by these cover types (Figs. 3 and 5). These differences can be an artifact of the fire modeling system used based on Rothermel fire spread model in those studies versus the Canadian Fire Behavior Prediction System in our study - plus differences in shrubland fuel characterization. We assumed low shrubs (up to $1 \mathrm{~m}$ height) with a mean fine fuel load $\left(5 \mathrm{tha}^{-1}\right)$ that characterizes the dominant medium-density shrublands ( $>65 \%$ of shrubland), while in Azevedo et al. (2011b) and Duguy et al. (2007), dense and tall $(\approx 2 \mathrm{~m}$ height) shrubland prevails, with heavy fuel load $\left(\approx 23 \mathrm{tha}^{-1}\right)$ favoring 


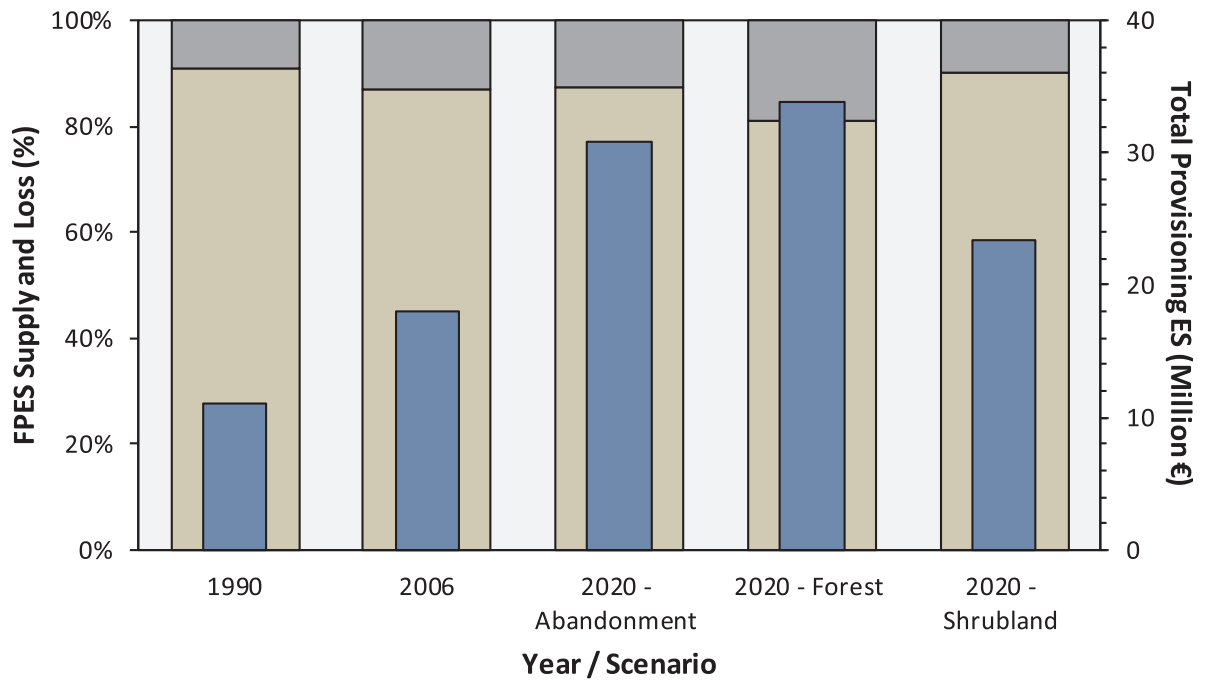

口FPES Supply $\quad$ FPES Loss $\square$ Max. Provisioning ES

Fig. 8. Variation of FPES supply (\%) as a proportion of the maximum economic value of the selected provisioning ES in the study area, and the corresponding firerelated losses (\%) among dates and alternative landscape scenarios.

fast and intense fires. However, comparison between our shrubland model and fuel model 5 (Anderson, 1982) used by Duguy et al. (2007) reveals similar fire behavior.

\subsection{Trends in fire protection ecosystem service}

The reduction in regulation capacity over time described above was also observed in the supply of FPES in the Sabor River's upper basin. From 1990 to 2020 there was a considerable growth in the supply and value of the provisioning ES considered in this work but reaching the highest levels in the case of the Forest expansion scenario. A very high supply of ES in a scenario of higher abundance of forests is also expected for other categories of ES in the same area (Sil et al., 2016). Over the same time interval, there was also a substantial growth in losses caused by simulated fires (Figs. 7 and 8). This growth in damage, however, was more than proportional in relation to ES value growth indicating a decrease in the FPES of the landscape. This means that although the supply and value of provisioning ES in the landscape tended to increase within the period of analysis, there was a stronger loss of the fire protection ES in the same period (Fig. 8). This trend was observed for changes in the landscape between 1990 (1 M€ losses in provisioning ES) and 2006 (2.4 M€) and between 1990 and any of the scenarios (4, 6.5 and 2.4 M€ for Abandonment, Forest, and Shrubland, respectively). This suggests the possibility of continuous decreasing FPES in the future in this area. Fire statistics for the Bragança Municipality, where the study area is located, show that there was an increase in mean burned area between the 1990s and mid-2000s (ICNF, 2015) and a decrease in the last decade. Nevertheless, large fire events may become more frequent (Fig. 4) under future scenarios, contributing to higher vulnerability of the natural values and socioeconomic system to wildfires, although extreme intensity fires may be reduced (Fig. 5).

Three levels of economic trade-offs between fire regulation and the provisioning functions were identified among scenarios (Fig. 8). These represent levels of potential fire-induced economic damage on provisioning ES related to the effects of landscape change on FRC and FPES. Despite the high potential economic benefits of forest expansion (Fig. 7), this scenario represents also a strong decrease in the FPES and its economic value (Figs. 7 and 8). Lower FPES and corresponding economic value are also expected in the Shrubland expansion scenario, although the potential economic losses will be the lowest among scenarios (Figs. 7 and 8). Yet the sustainable supply of the provisioning ES in the future may also be affected negatively in this case (Figs. 7 and 8). The effect of FPES loss in the Rural abandonment scenario is intermediate between the other scenarios (Fig. 8), suggesting that high levels of provisioning ES may be maintained in the future (Fig. 7) and, simultaneously, the mitigation of extreme fire intensity events (Fig. 5) at the expenses of moderated potential economic losses (Fig. 7) may occur as well, although fire size tends to increase as in the other two scenarios (Figs. 3a and 6).

Our results followed the pattern of the estimated economic losses (suppression costs not included) reported for the Bragança municipality (ICNF, 2015) during 1990 and mid-2000s. However, ICNF (2015) reports that economic losses in the area are currently decreasing, which is only comparable to the Shrubland expansion scenario (Fig. 7). Nevertheless, our estimates tend to be higher, which may be explained primarily by the fact that we are comparing simulated with actual fires that depend on actual weather conditions, ignitions and fire suppression (constant or not addressed in our modeling exercise) and by the different valuation methods applied in damage evaluation. We used the supply and value of three provisioning ES and mean burned areas $\left(1021 € \mathrm{ha}^{-1}\right.$ in $1990,2222 € \mathrm{ha}^{-1}$ in $2006,3038 € \mathrm{ha}^{-1}$ in $2020-$ Rural abandonment, $3430 € \mathrm{ha}^{-1}$ in 2020 - Forest expansion, and $2795 € \mathrm{ha}^{-1}$ in 2020 - Shrubland expansion), while ICNF (2015) estimates used a constant value $\left(1435 € \mathrm{ha}^{-1}\right)$, regardless of the potential changes in the provision of natural values in the area.

The estimates reported by Madureira et al. (2013) for the value of the fire regulation ES, based on stated preferences methods averaged $276.2 € \mathrm{ha}^{-1}$, thus are much lower than ours. Similarly, estimates reported by Parthum et al. (2017) for the value of fire mitigation ES, are much lower than our estimates, considering the avoided costs of a single wildfire on the public health system $\left(7.5 € \mathrm{ha}^{-1}\right.$ year (1US Dollar $=0.94 €)$ ). Conversely, the fire regulation ES estimated for Spanish ecosystems (Román et al., 2013) using revealed preferences techniques is much higher (2229 $\mathrm{T} € \mathrm{ha}^{-1}$ on average) than our estimates.

Ninan and Kontoleon (2016), using an ESD conceptual approach, reported a value of $2.1 € \mathrm{ha}^{-1}$ per year (1US Dollar $=0.94 €$ ) for the compensation paid by state forest authorities for wildfire damage and the social damage value of carbon emissions by fires, which is much lower than our estimates. Overall, differences found among studies may be partially explained by different valuation methods applied, but also due to different conceptual basis of the assessment and the different 
definitions for fire regulating ES used by authors, which may hamper the comparison between studies, and a better perception of the economic value of the service to implement future schemes of payment for ecosystem services.

\subsection{Management implications}

This study highlighted that landscape change, driven by farmland abandonment, is a determinant factor in the modification of fire behavior patterns, the Fire Regulation Capacity and the supply of the Forest Protection Ecosystem Service in the Sabor River's upper basin landscape. Our results suggest that landscape changes favoring fuel continuity and more hazardous fuels, then larger fires may occur which agrees with findings elsewhere in the Mediterranean Europe (Fernandes et al., 2016b; Koutsias et al., 2015; Pausas and Fernández-Muñoz, 2012; Pereira et al., 2013; San-Miguel-Ayanz et al., 2013; Turco et al., 2017). Also, under severe weather conditions, more extreme intensity fire behavior is expected to occur (Palheiro et al., 2006; Taylor et al., 1996), particularly if conifer stands dominate the landscape (Pinto and Fernandes, 2014), which may increase suppression difficulty (Alexander and Lanoville, 1989) and economic losses, resulting in growing vulnerability of people and their livelihoods to wildfire.

The patterns identified in this study suggest, therefore, that maintaining a heterogeneous landscape structure may increase the capacity to moderate extreme fire events. This is particularly relevant under future global change scenarios, i.e. to maintain or to increase FRC and FPES in landscapes in the future. This is crucial for mitigating immediate fire impacts on human communities but also to increase ecosystem resiliency to fire (Torres et al., 2018), maintaining the provision of essential ES by the landscape. However, this will largely depend on planning and management, which to this aim should focus mainly on preventive measures related to fuel treatments, fuel type conversion and landscape structure optimization (Fernandes, 2013; Fernandes et al., 2013; Smith et al., 2016).

Land planning and management of this and other fire-prone areas should consider the maintenance of a diverse plant composition in the landscape, allowing natural fuel breaks to disrupt continuous highlyflammable cover types (Fernandes et al., 2010; Oliveira et al., 2016) and the use of less fire-prone forest species in afforestation programs and projects (Azevedo et al., 2013), combined with fuel hazard reduction through silvicultural and fuel treatments, particularly in conifer stands (e.g. Fernandes and Rigolot, 2007; Fernandes et al., 2004); the use of prescribed burning to reduce fuels, moderating wildfire impacts and facilitating its suppression (Fernandes, 2015; Fernandes et al., 2013); and the maintenance of traditional activities (e.g. grazing), jointly with prescribed burning (Honrado et al., 2017; Mateus and Fernandes, 2014). In addition, changes at the policy level are also required. The fire suppression oriented policy followed in the country for many decades may have contributed to fuel buildup in the landscape (Collins et al., 2013; Mateus and Fernandes, 2014). Also, forest planning and policy in Portugal has favored the expansion of monocultures of highly fire-prone species which, if not properly managed, contribute to increasing fire hazard (Moreira et al., 2011).

This study underlined the economic importance of FPES, given the impact of fire on other ES provisioned by the landscape. Assessing the economic value of existing natural resources, as well as the potential costs associated with possible threats, may be an important step towards diversifying economic activities in mountain regions, where rural abandonment is possibly irreversible, but also a way to raise awareness regarding the need to address fire management among landowners, communities, and agents involved in managing these fire-prone areas. Fire management actions as those described above may reduce economic losses due to wildfires, and enable higher supply of other valuable ES, as well as maintain traditional activities that may help to slow down rural abandonment. The development of collaborative measures to support the economic costs of management actions is urgently needed. These may be achieved through the payments of ES, that would directly revert to fire risk reduction (Jones et al., 2017; Miller et al., 2017), and to preserve and increase regular ES supply.

Limitations arose in simulating fire behavior (e.g. simplification of land cover and fuel types, and fire weather conditions for the entire area), as well as in establishing future landscape scenarios for the area, which should be improved in future research. Also, the valuation of the fire protection ES should be improved. Although the impact of fire on traded market goods supply is of very high importance, it may be still insufficient to attain the "true" value of the service, since many ES may not be valued in conventional trade markets (e.g., cultural services (de Groot et al., 2010)). Thus, a more comprehensive valuation should be taken (Pascual et al., 2017), including, e.g., the demand for goods in the provisioning ES valuation estimates (Mouchet et al., 2014), the willingness to pay for fire regulation (Madureira et al., 2013), the inclusion of regulating services (e.g. carbon sequestration) that are directly affected by fire as part of the assessment (Carvalho et al., 2011), as well as costs related to fuel management (Jones et al., 2017), fire suppression and environmental restoration (Lee et al., 2015), and human life (Parthum et al., 2017; Román et al., 2013). Nonetheless, the results of this study are useful to establish baselines for future management and planning to support decision-making based on past and future alternative landscape scenarios trends.

\section{Conclusions}

Wildfires and their potentially harmful effects on humans and their livelihoods can be regulated by landscapes. The assessment of landscape changes is very urgent since these drive the landscape fire regulating capacity, particularly in the context of climate aggravation, and the supply of the fire protection ES.

In this study we observed that landscape changes taking place since the 1990s are decreasing the regulating capacity of the landscape as well as it the supply and value of FPES in a mountain region in the North of Portugal. Simulated fire behavior metrics used as indicators of landscape capacity to regulate fire and an evaluation of losses in the supply of three provisioning ES allowed the identification of trends in FPES, highlighting different levels of economic trade-offs between fire regulation and provisioning functions in the landscape, which may be relevant to better support future planning and management in this and other fire-prone areas.

This study can assist private and public land owners and managers to better understand the relationships between LULC, FRC, FPES and environmental and economic effects of wildfires, and to integrate adaptive strategies to cope with possible trade-offs between ES supply and fire regulation, particularly in fire-prone mountain regions experiencing land abandonment, typically socioeconomically vulnerable to climate and disturbance regime shifts.

Therefore, we recommend that the management and planning of areas affected by farmland abandonment should focus on actions towards the maintenance of landscape heterogeneity, since this is of the utmost important to the regulation of wildfires and consequently increase the capacity of protection of people and their livelihoods, and to maintain the supply of other ES, contributing to the sustainable development of these regions. Landscapes in these areas, therefore, should be kept diversified both in terms of its configuration, allowing the existence of a landscape mosaic with different land uses and covers that disrupts the fire spread, thus helping to prevent the occurrence of large fires, and also in terms of its composition, since that maintaining the landscape balanced in terms of species composition allow to reduce areas that may burn at extreme fire intensities and increases the capacity to control fires.

\section{Acknowledgements}

Â. Sil received support from the Portuguese Foundation for Science 
and Technology (FCT) through Ph.D Grant SFRH/BD/132838/2017. This research was partially funded by the European Regional Development Fund (ERDF) through the Operational Programme for Competitiveness Factors-COMPETE and by Portuguese national funds through the Foundation for Science and Technology (FCT) under the projects PTDC/AAG-MAA/4539/2012/FCOMP-01-0124-FEDER027863 (IND_CHANGE) and UID/AGR/04033/2019. We thank two anonymous reviewers and the editor for extremely valuable comments and suggestions on the manuscript.

\section{Declarations of interest}

None

\section{Appendix A. Supplementary data}

Supplementary data to this article can be found online at https:// doi.org/10.1016/j.ecoser.2019.100908.

\section{References}

Alcamo, J., Ash, N., Bennett, E., Biggs, R., Butler, C., Callicott, J., Capistrano, D., Carpenter, S., Castilla, J., Chambers, R., Choo, P., Chopra, K., Cropper, A., Daily, G., Dasgupta, P., de Groot, R., Dietz, T., Duraiappah, A., Foley, J., Gadgil, M., Hamilton, K., Hassan, R., Kumar, P., Lambin, E., Lebel, L., Lee, M., Leemans, R., Jiyuan, L., Malingreau, J., May, R., McCalla, A., McMichael, T., et al., 2003. Ecosystems and Human Well-being: A Framework for Assessment. Island Press, Washington, pp. 49-70.

Alexander, M.E., Lanoville, R.A., 1989. Predicting Fire Behavior in the Black SpruceLichen Woodland Fuel Type of Western and Northern Canada. Canadian Forestry Service, Northwest Region, Edmonton, Alberta, Government of Northwest Territories, Department of Renewable Resources, Territorial Forest Fire Centre, Fort Smith, Northwest Territories; p. 17.

Anderson, H., 1982. Aids to Determining Fuel Models for Estimating Fire Behavior. General Technical Report INT-122. U. S. Department of Agriculture, Forest Service, Intermountain Forest and Range Experiment Station, Ogden, Utah, pp. 22.

Azevedo, J.C., Castro, J.P., Pinheiro, H., Moreira, C., Magalhães, S., Loureiro, C., Fernandes, P., 2011a. Dinâmica e serviços da paisagem no Nordeste de Portugal. In: Neto, J., Einloft, C., Gonçalves, R. (Eds.), Desenvolvimento rural, Sustentabilidade e Ordenamento territorial. Suprema, Visconde do Rio Branco, MG, pp. 158-174.

Azevedo, J.C., Moreira, C., Castro, J.P., Loureiro, C., 2011b. Agriculture abandonment, land use change and fire hazard in mountain landscapes in northerastern Portugal. In: Li, C., Lafortezza, R., Chen, J. (Eds.), Landscape Ecology in Forest Management and Conservation: Challenges and Solutions for Global Change. Springer, New York, pp. 329-351.

Azevedo, J.C., Possacos, A., Aguiar, C., Amado, A., Miguel, L., Dias, R., Loureiro, C., Fernandes, P., 2013. The role of Holm oak edges in the control of disturbance and conservation of plant diversity in fire-prone landscapes. For. Ecol. Manage. 297, 37-48.

Barros, A.M.G., Pereira, J.M.C., 2014. Wildfire selectivity for land cover type: Does size matter? PLOS ONE 9 (1), e84760.

Barros, A., Pereira, J., Lund, U., 2012. Identifying geographical patterns of wildfire orientation: a watershed-based analysis. For. Ecol. Manage. 264, 98-107.

Benayas, J.M.R., Martins, A., Nicolau, J.M., Schulz, J.J., 2007. Abandonment of agricultural land: an overview of drivers and consequences. CAB Rev.: Perspect. Agri. Veterinary Sci. Nutr. Nat. Resour. 2, 1-12.

Bernués, A., Rodríguez-Ortega, T., Ripoll-Bosch, R., Alfnes, F., 2014. Socio-cultural and economic valuation of ecosystem services provided by Mediterranean mountain agroecosystems. PLoS ONE 9, e102479.

Bond, W.J., Keane, R.E., 2017. Fires, Ecological Effects of Sciences. Elsevier, Amsterdam, pp. 11.

Bowman, D., Balch, J., Artaxo, P., Bond, W., Carlson, J., Cochrane, M., D’Antonio, C., DeFries, R., Doyle, J., Harrison, S., Johnston, F., Keeley, J., Krawchuk, M., Kull, C., Marston, J., Moritz, M., Prentice, C., Roos, C., Scott, A., Swetnam, T., van der Werf, G., Pyne, S., 2009. Fire in the earth system. Science 324, 481-484.

Bowman, D., Balch, J., Artaxo, P., Bond, W., Cochrane, M., D’Antonio, C., DeFries, R., Johnston, F., Keeley, J., Krawchuk, M., Kull, C., Mack, M., Moritz, M., Pyne, S., Roos, C., Scott, A., Sodhi, N., Swetnam, T., Whittaker, R., 2011. The human dimension of fire regimes on Earth. J. Biogeogr. 38, 2223-2236.

Byram, G.M., 1959. Combustion of forest fuels. Chap. 3. In: Davis, K.P. (Ed.), Forest Fire: Control and Use. McGraw Hill, New York, pp. 61-89.

Carmo, M., Moreira, F., Casimiro, P., Vaz, P., 2011. Land use and topography influences on wildfire occurrence in northern Portugal. Landscape Urban Plann. 100, 169-176.

Carvalho, A., Monteiro, A., Flannigan, M., Solman, S., Miranda, A., Borrego, C., 2011. Forest fires in a changing climate and their impacts on air quality. Atmos. Environ. 45, 5545-5553.

Carvalho, J.P., 2000. Crescimento, produção e ecologia de povoamentos de Quercus pyrenaica Willd. Portugal continental. Universidade de Trás os-Montes e Alto Douro, Vila Real.
Carvalho-Santos, C., Monteiro, A.T., Azevedo, J.C., Honrado, J., Nunes, J.P., 2017. Climate change impacts on water resources and reservoir management: uncertainty and adaptation for a mountain catchment in northeast Portugal. Water Resour. Manage. 31, 3355-3370.

Chuvieco, E., Giglio, L., Justice, C., 2008. Global characterization of fire activity: toward defining fire regimes from Earth observation data. Glob. Change Biol. 14, 1488-1502.

Collins, R., Neufville, R., Claro, J., Oliveira, T., Pacheco, A.P., 2013. Forest fire management to avoid unintended consequences: a case study of Portugal using system dynamics. J. Environ. Manage. 130, 1-9.

Czúcz, B., Arany, I., Potschin-Young, M., Bereczki, K., Kertész, M., Kiss, M., Aszalós, R., Haines-Young, R., 2018. Where concepts meet the real world: a systematic review of ecosystem service indicators and their classification using CICES. Ecosyst. Serv. 29 (Part A), 145-157.

de Groot, R., Alkemade, R., Braat, L., Hein, L., Willemen, L., 2010. Challenges in integrating the concept of ecosystem services and values in landscape planning, management and decision making. Ecol. Complexity 7, 260-272.

de Guenni, B., Cardoso, M., Goldammer, J., Hurtt, G., Mata, J., 2005. Regulation of natural hazards: floods and fires. Chap. 16. In: Hassan, R., Scholes, R., Ash, N. (Eds.), Ecosystems and Human Well-being. Current State and Trends Assessment. Island Press, Washington, pp. 441-454.

Dubrovský, M., Hayes, M., Duce, P., Trnka, M., Svoboda, M., Zara, P., 2014. Multi-GCM projections of future drought and climate variability indicators for the Mediterranean region. Reg. Environ. Change 14, 1907-1919.

Duguy, B., Alloza, J., Roder, A., Vallejo, R., Pastor, F., 2007. Modelling the effects of landscape fuel treatments on fire growth and behaviour in a Mediterranean landscape (eastern Spain). Int. J. Wildland Fire 16, 619-632.

Duro, M.R.G., 2008. Vendas de madeira nos perímetros florestais do Barroso-Padrela factores relevantes na formação do preço. Universidade de Trás-os-Montes e Alto Douro, Vila Real, Portugal.

Fernandes, P., 2009. Combining forest structure data and fuel modelling to classify fire hazard in Portugal. Ann. For. Sci. 66, 415.

Fernandes, P., 2013. Fire-smart management of forest landscapes in the Mediterranean basin under global change. Landscape Urban Plann. 110, 175-182.

Fernandes, P.M., 2015. Empirical support for the use of prescribed burning as a fuel treatment. Curr. Forestry Rep. 1, 118.

Fernandes, P., Loureiro, C., Botelho, H., 2004. Fire behaviour and severity in a maritime pine stand under differing fuel conditions. Ann. For. Sci. 61, 537-544.

Fernandes, P., Rigolot, E., 2007. The fire ecology and management of maritime pine (Pinus pinaster Ait.). For. Ecol. Manage. 241, 1-13.

Fernandes, P., Luz, A., Loureiro, C., 2010. Changes in wildfire severity from maritime pine woodland to contiguous forest types in the mountains of northwestern Portugal. For. Ecol. Manage. 260, 883-892.

Fernandes, P., Davies, G.M., Ascoli, D., Fernández, C., Moreira, F., Rigolot, E., Stoof, C.R., Vega, J.A., Molina, D., 2013. Prescribed burning in southern Europe: developing fire management in a dynamic landscape. Front. Ecol. Environ. 11, e4-e14.

Fernandes, P., Loureiro, C., Guiomar, N., Pezzatti, G.B., Manso, F.T., Lopes, L., 2014. The dynamics and drivers of fuel and fire in the Portuguese public forest. J. Environ. Manage. 146, 373-382.

Fernandes, P., Pacheco, A., Almeida, R., Claro, J., 2016a. The role of fire-suppression force in limiting the spread of extremely large forest fires in Portugal. Eur. J. Forest Res. 135, 253-262.

Fernandes, P., Monteiro-Henriques, T., Guiomar, N., Loureiro, C., Barros, A., 2016b. Bottom-up variables govern large-fire size in Portugal. Ecosystems 19, 1362-1375.

Forestry Canada Fire Danger Group, 1992. Development and Structure of the Canadian Forest Fire Behavior Prediction System Information Report ST-X-3. Forestry Canada Science and Sustainable Development Directorate, Ottawa, pp. 63.

Ganteaume, A., Camia, A., Jappiot, M., San Miguel-Ayanz, J., Long-Fournel, M., Lampin, C., 2013. A review of the main driving factors of forest fire ignition over Europe. Environ. Manage. 51, 651-662.

Garcia, M.M., Carvalheira, M., Azevedo, J., 2006. Contribuicão para a caracterizacão da recolha comercial de macrofungos comestíveis no Distrito de Bragança, Portugal. Pantorra 6, 141-153.

Gonçalves, J.A., Morgado, A., 2008. Use of the SRTM DEM as a geo-referencing tool by elevation matching. Int. Arch. Photogram. Remote Sens. Spatial Info. Sci. XXXVII (Part B2), 879-883 Beijing.

Haines-Young, R., Potschin, M.B., 2018. Common International Classification of Ecosystem Services (CICES) V5.1 and Guidance on the Application of the Revised Structure. Available from www.cices.eu.

Halofsky, J.A., Halofsky, J.E., Hemstrom, M.A., Morzillo, A.T., Zhou, X., Donato, D.C. 2017. Divergent trends in ecosystem services under different climate-management futures in a fire-prone forest landscape. Clim. Change 142, 83-95.

Honrado, J.P., Lomba, A., Alves, P., Aguiar, C., Monteiro-Henriques, T., Cerqueira, Y., Monteiro, P., Barreto, Caldas F., 2017. Conservation management of EU priority habitats after collapse of traditional pastoralism: navigating socioecological transitions in mountain rangeland. Rural Sociol. 82, 101-128.

Hutto, R.L., 2008. The ecological importance of severe wildfires: some like it hot. Ecol. Appl. 18, 8.

IBM Corp., 2011. IBM SPSS Statistics for Windows, Version 20.0. IBM Corp, Armonk, NY.

ICNF - Instituto da Conservação da Natureza e das Florestas. 2015. Portuguese forest fire management system statistics. Available from: http://www.icnf.pt/portal/florestas/ dfci/inc/estat-sgif (Data accessed: 20-03-2017).

ICNF - Instituto da Conservação da Natureza e das Florestas. 2017. Annual report of forest fires in Portuguese mainland for 2017 (provisional report). Available from: http:// www.icnf.pt/portal/florestas/dfci/relat/rel-if/2017 (Data accessed: 20-11-2017).

Jones, K.W., Cannon, J.B., Saavedra, F.A., Kampf, S.K., Addington, R.N., Cheng, A.S., MacDonald, L.H., Wilson, C., Wolk, B., 2017. Return on investment from fuel 
treatments to reduce severe wildfire and erosion in a watershed investment program in Colorado. J. Environ. Manage. 198, 66-77.

Keane, R.E., Agee, J.K., Fule, P., Keeley, J.E., Key, C., Kitchen, S.G., Miller, R., Schulte, L.A., 2008. Ecological effects of large fires on US landscapes: benefit or catastrophe. Int. J. Wildland Fire 17, 696-712.

Koutsias, N., Arianoutsou, M., Kallimanis, A., Mallinis, G., Halley, J., Dimopoulos, P., 2015. Where did the fires burn in Peloponnisos, Greece the summer of 2007? Evidence for a synergy of fuel and weather. Agric. For. Meteorol. 156, 41-53.

Krebs, P., Pezzatti, G.B., Mazzoleni, S., Talbot, L.M., Conedera, M., 2010. Fire regime: history and definition of a key concept in disturbance ecology. Theory Biosci. 129, 53.

Kuemmerle, T., Levers, C., Erb, K., Estel, S., Jepsen, M., Müller, D., Plutzar, C., Stürck, J., Verkerk, P., Verburg, P., Reenberg, A., 2016. Hotspots of land use change in Europe. Environ. Res. Lett. 11, 064020.

Krawchuk, M.A., Moritz, M.A., Parisien, M.A., Van Dorn, J., Hayhoe, K., 2009. Global pyrogeography: the current and future distribution of wildfire. PLoS ONE 4, e5102.

Layke, C., 2009. Measuring Nature's Benefits: A Preliminary Roadmap for Improving Ecosystem Service Indicators. WRI Working Paper. World Resources Institute, Washington, pp. 36.

Lee, C., Schlemme, C., Murray, M., Unsworth, R., 2015. The cost of climate change: ecosystem services and wildland fires. Ecol. Econ. 116, 261-269.

Lloret, F., Calvo, E., Pons, X., Díaz-Delgado, R., 2002. Wildfires and landscape patterns in the Eastern Iberian Peninsula. Landscape Ecol. 17, 745-759.

MacDonald, D., Crabtree, J., Wiesinger, G., Dax, T., Stamou, N., Fleury, P., Lazpita, J., Gibon, A., 2000. Agricultural abandonment in mountain areas of Europe: environmental consequences and policy response. J. Environ. Manage. 59, 47-69.

Maes, J., Braat, L., Jax, K., Hutchins, M., Furman, E., Termansen, M., Luque, S., Paracchini, M.L., Chauvin, C., Williams, R., Volk, M., Lautenbach, S., Kopperoinen, L., Schelhaas, M., Weinert, J., Goossen, M., Dumont, E., Strauch, M., Görg, C., Dormann, C., et al., 2011. A Spatial Assessment of Ecosystem Services in Europe: Methods, Case Studies and Policy Analysis - Phase 1. PEER Report No 3. Partnership for European Environmental Research, Ispra.

Madureira, L., Magalhães, P., Silva, P., Marinho, C., Oliveira, R., 2013. Economia dos Serviços de Ecossistema - Um guia para conhecer e valorizar serviços de agroecossistemas em áreas protegidas de montanha. Quercus - Associação Nacional de Conservação da Natureza, Lisboa, pp. 146.

Magalhães, S.R., Ribeiro, C.A.A.S., Castro, J.M.C.S.F., Fernandes, P.A.M., Silva, C.A.R.L., Pinheiro, H.M.P., Azevedo, J.C.M., 2017. Fire behaviour in different periods and configurations of a landscape in Northeastern Portugal. Ciência Florestal 27, 457-469.

Martín-Martín, C., Bunce, R., Saura, S., Elena-Rosselló, R., 2013. Changes and interactions between forest landscape connectivity and burnt area in Spain. Ecol. Ind. 33, 129-138.

Mateus, P., Fernandes, P., 2014. Forest fires in Portugal: dynamics, causes and policies. Chap. 4. In: Reboredo, F. (Ed.), Forest Context and Policies in Portugal: Present and Future Challenges. World Forest, pp. 97-115.

McKenzie, D., Miller, C., Falk, D.A., 2011. Toward a theory of landscape fire. Chap. 1. In: McKenzie, D., Miller, C., Falk, D.A. (Eds.), The Landscape Ecology of Fire. Springer, Netherlands, pp. 3-25.

Millennium Ecosystem Assessment, 2005. MA conceptual framework. In: Hassan, R., Scholes, R., Ash, N. (Eds.), Ecosystems and Human Well-being: Current State and Trends. Island Press, Washington, pp. 25-36.

Miller, R., Nielsen, E., Huang, C.H., 2017. Ecosystem service valuation through wildfire risk mitigation: design, governance, and outcomes of the flagstaff watershed protection project (FWPP). Forests 8, 142

Monteiro, L., 2011. A Importância da Análise da Vulnerabilidade na Gestão do Risco de Incêndio Florestal: Algumas Evidências no Concelho de Bragança. Faculdade de Letras da Universidade do Porto, Porto.

Montiel, C., Galiana-Martín, L., 2016. Fire scenarios in Spain: a territorial approach to proactive fire management in the context of global change. Forests 7, 273.

Moreira, C., Castro, J.P., Azevedo, J.C., 2008. Landscape change in a mountainous area in northeastern Portugal: implications for management. In: Panagopoulos, T., Burley, J., Celikyay, S. (Eds.), New Aspects of Urban Planning and Transportation. Proceedings of the WSEAS International Conference on Urban Planning and Transportation (UPT'07); July 22-24; Heraklion. WSEAS Press, Crete Island (Greece).

Moreira, F., Viedma, O., Arianoutsou, M., Curt, T., Koutsias, N., Rigolot, E., Barbati, A., Corona, P., Vaz, P., Xanthopoulos, G., Mouillot, F., Bilgili, E., 2011. Landscape wildfire interactions in southern Europe: implications for landscape management. J. Environ. Manage. 92, 2389-2402.

Moriondo, M., Good, P., Durao, R., Bindi, M., Giannakopoulos, C., Corte-Real, J., 2006. Potential impact of climate change on fire risk in the Mediterranean area. Climate Res. 31, 85-95.

Mouchet, M., Lamarque, P., Martín-López, B., Crouzat, E., Gos, P., Byczek, C., Lavorel, S., 2014. An interdisciplinary methodological guide for quantifying associations between ecosystem services. Global Environ. Change 28, 298-308.

Ninan, K., Kontoleon, A., 2016. Valuing forest ecosystem services and disservices - case study of a protected area in India. Ecosyst. Serv. 20, 1-14.

Oliveira, T., Barros, A., Ager, A., Fernandes, P., 2016. Assessing the effect of a fuel break network to reduce burnt area and wildfire risk transmission. Int. J. Wildland Fire 25, 619-632.

Palheiro, P., Fernandes, P., Cruz, M., 2006. A fire behaviour-based fire danger classification for maritime pine stands: comparison of two approaches. Forest Ecol. Manage. 234 S: S54 - S54.

Parthum, B., Pindilli, E., Hogan, D., 2017. Benefits of the fire mitigation ecosystem service in The Great Dismal Swamp National Wildlife Refuge, Virginia, USA. J. Environ. Manage. 203, 375-382.
Pascual, U., Balvanera, P., Díaz, S., Pataki, G., Roth, E., Stenseke, M., Watson, R.T., Dessane, E.B., Islar, M., Kelemen, E., et al., 2017. Valuing nature's contributions to people: the IPBES approach. Curr. Opin. Environ. Sustainability 26-27, 7-16.

Pascual, U., Muradian, R., Brander, L., Gómez-Baggethun, E., Martín-López, M., Verman, M., Armsworth, P., Christie, M., Cornelissen, H., Eppink, F., et al., 2010. The economics of valuing ecosystem services and biodiversity. In: Kumar, P. (Ed.), The Economics of Ecosystems and Biodiversity Ecological and Economic Foundations. Routledge, London, pp. 183-256.

Pausas, J.G., 2006. Simulating mediterranean landscape pattern and vegetation dynamics under different fire regimes. Plant Ecol. 187, 249-259.

Pausas, J., Fernández-Muñoz, S., 2012. Fire regime changes in the Western Mediterranean Basin: from fuel-limited to drought-driven fire regime. Clim. Change 110, 215-226.

Pechony, O., Shindell, D.T., 2010. Driving forces of global wildfires over the past millennium and the forthcoming century. Proc. Natl. Acad. Sci. 107, 45.

Pereira, M., Calado, T., DaCamara, C., Calheiros, T., 2013. Effects of regional climate change on rural fires in Portugal. Clim. Res. 57, 187-200.

Perera, A., Ouellette, M., Cui, W., Drescher, M., Boychuk, D., 2008. BFOLDS 1.0: A Spatial Simulation Model for Exploring Large Scale Fire Regimes and Succession in Boreal Forest Landscapes. Forest Research Report No. 152. Ontario Ministry of Natural Resources, Ontario Forest Research Institute, Sault Ste. Marie, ON, pp. 50.

Perera, A., Ouellette, M., Boychuc, D., 2014. BFOLDS Fire Regime Module v2.0: User Guide for LANDIS-II Extension. Ontario Ministry of Natural Resources, Ontario Forest Research Institute, Sault Ste. Marie, ON, pp. 33.

Pérez-Rodríguez, F., Nunes, L., Sil, Â., Azevedo, J.C., 2016,. Flornext ${ }^{\oplus}$, a cloud computing application to estimate growth and yield of maritime pine (pinus pinaster ait.) stands in northeastern portugal, a cloud computing application to estimate growth and yield of maritime pine (Pinus pinaster Ait.) stands in northeastern Portugal. For Syst. 25 (2), 6. https://doi.org/10.5424/fs/2016252-08975. eRC08.

Pettorelli, N., Schulte to Bühne, H., Tulloch, A., Dubois, G., Macinnis-Ng, C., Queirós, A.M., Keith, D.A., Wegmann, M., Schrodt, F., Stellmes, M., Sonnenschein, R., Geller, G.N., Roy, S., Somers, B., Murray, N., Bland, L., Geijzendorffer, I., Kerr, J.T., Broszeit, S., Leitão, P.J., Duncan, C., El Serafy, G., He, K.S., Blanchard, J.L., Lucas, R., Mairota, P., Webb, T.J., Nicholson, E., 2017. Satellite remote sensing of ecosystem functions: opportunities, challenges and way forward. Remote Sens. Ecol. Conserv. 4, 71-93.

Pinheiro, H., Castro, J.P., Azevedo, J.C., 2014. Alterações napaisagem e sequestro de carbono na freguesia de Deilão, nordeste de Portugal. Rev Arv. 38, 41-52.

Pinto, A., Fernandes, P., 2014. Microclimate and modeled fire behavior differ between adjacent forest types in Northern Portugal. Forests 5, 2490-2504.

Poyatos, R., Latron, J., Llorens, P., 2003. Land use and land cover change after agricultural abandonment. Mt. Res. Dev. 23, 362-368.

Rachdi, S., 2016. Simulating the Effects of Vegetation and Landscape Structure on Fire Behavior in Northeastern Portugal: The Case of Holm Oak (Quercus rotundifolia). Instituto Politécnico de Bragança, Bragança.

Rego, F., Louro, G., Constantino, L., 2013. The impact of changing wildfire regimes on wood availability from Portuguese forests. Forest Policy Econ. 29, 56-61.

Rodrigues, A.P.P., 2015. Quantificação, valoração e mapeamento de serviços de ecossistema na bacia superior do Rio Sabor (concelho de Bragança). Instituto Politécnico de Bragança, Bragança, Portugal.

Román, M., Azqueta, D., Rodrígues, M., 2013. Methodological approach to assess the socio-economic vulnerability to wildfires in Spain. For. Ecol. Manage. 294, 158-165.

Rothermel, R.C., 1983. How to Predict the Spread and Intensity of Forest and Range Fires. Gen. Tech. Rep. INT-143. Department of Agriculture, Forest Service, Intermountain Forest and Range Experiment Station, Ogden, UT, USA, pp. 161.

San-Miguel-Ayanz, J., Durrant, T., Boca, R., Libertà, G., Branco, A., de Rigo, D., Ferrari, D., Maianti, P., Vivancos, T.A., Schulte, E., Loffler, P., 2017. Forest Fires in Europe, Middle East and North Africa 2016. EUR 28707 EN. Publications Office, Luxembourg, pp. 120.

San-Miguel-Ayanz, J., Moreno, J., Camia, A., 2013. Analysis of large fires in European Mediterranean landscapes: lessons learned and perspectives. For. Ecol. Manage. 294, $11-22$.

Scheller, R., Domingo, J., Sturtevant, B., Williams, J., Rudy, A., Gustafson, E., Mladenoff, D., 2007. Design, development, and application of LANDIS-II, a spatial landscape simulation model with flexible temporal and spatial resolution. Ecol. Model. 201, 409-419.

Shackleton, C., Ruwanza, S., Sinasson, S., Bennett, S., Lacy, P., Modipa, R., Mtati, N., Sachikonye, M., Thondhlana, G., 2016. Unpacking Pandora's Box: understanding and categorising ecosystem disservices for environmental management and human wellbeing. Ecosystems 19, 587-600.

Sil, Â., Rodrigues, A., Carvalho-Santos, C., Nunes, J., Honrado, J., Alonso, J., MartaPedroso, C., Azevedo, J.C., 2016. Trade-offs and synergies between provisioning and regulating ecosystem services in a mountain area in Portugal affected by landscape change. Mt. Res. Dev. 36, 452-464.

Sil, Â., Fonseca, F., Gonçalves, J., Honrado, J., Marta-Pedroso, C., Alonso, J., Ramos, M., Azevedo, J.C., 2017. Analysing carbon sequestration and storage dynamics in a changing mountain landscape in Portugal: insights for management and planning. Int. J. Biodiver. Sci. Ecosyst. Serv. Manage. 13, 82-104.

Silva, J., Vaz, P., Moreira, F., Catry, F., Rego, F., 2011. Wildfires as a major driver of landscape dynamics in three fire-prone areas of Portugal. Landscape Urban Plann. $101,349-358$.

Smith, A., Kolden, C., Paveglio, T., Cochrane, M., Bowman, D., Moritz, M., Kliskey, A., Alessa, L., Hudak, A., Hoffman, C., Lutz, J., Queen, L., Goetz, S., Higuera, P., Boschetti, L., Flannigan, M., Yedinak, K., Watts, A., Strand, E., van Wagtendonk, J., Anderson, J., Stocks, B., Abatzoglou, J., 2016. The science of firescapes: achieving fire-resilient communities. Bioscience 66, 130-146.

Sugihara, N.G., van Wagtendonk, J.W., Fites-Kaufman, J., 2004. Fire as an ecological process. Chap. 4. In: Sugihara, N.G., van Wagtendonk, J.W., Fites-Kaufman, J., 
Shaffer, K.E., Thode, A.E. (Eds.), Fire in California Ecosystems. University of California Press, Berkeley, CA, USA, pp. 58-74.

Taylor, S., Pike, R., Alexander, M., 1996. Field Guide to the Canadian Forest Fire Behavior Prediction (FBP) System. FRDA Handbook. Canada-British Columbia Partnership Agreement on Forest Resource Development: FRDA II, B.C. Ministry of Forests and Northern Forestry Centre, Edmonton, Alberta, pp. 59.

Torres, J., Gonçalves, J., Marcos, B., Honrado, J., 2018. Indicator-based assessment of post-fire recovery dynamics using satellite NDVI time-series. Ecol. Ind. 89, 199-212.

Turco, M., von Hardenberg, J., AghaKouchak, A., Llasat, M., Provenzale, A., Trigo, R., 2017. On the key role of droughts in the dynamics of summer fires in Mediterranean Europe. Sci. Rep. 7, 81.

Turner, M.G., Donato, D.C., Romme, W.H., 2013. Consequences of spatial heterogeneity for ecosystem services in changing forest landscapes: priorities for future research. Landscape Ecol. 28, 1081.

Turner, M.G., Gardner, R.H., O’Neill, R.V., 2001. Landscape disturbance dynamics. In: Turner, M.G., Gardner, R.H., O’Neill, R.V. (Eds.), Landscape Ecology in Theory and Practice. Springer, New York, pp. 157-199. van Wagtendonk, J.W., 2004. Fire as a physical process. Chap. 3. In: Sugihara, N.G., van Wagtendonk, J.W., Fites-Kaufman, J., Shaffer, K.E., Thode, A.E. (Eds.), Fire in California Ecosystems. University of California Press, Berkeley, CA, USA, pp. 38-57. Vaz, A., Kueffer, C., Kull, C., Richardson, D., Vicente, J., Kühn, I., Schröter, M., Hauck, J., Bonn, A., Honrado, J., 2017. Integrating ecosystem services and disservices: insights from plant invasions. Ecosyst. Serv. 23, 94-107.

Viedma, O., Angeler, D.G., Moreno, J.M., 2009. Landscape structural features control fire size in a Mediterranean forested area in central Spain. Int. J. Wildland Fire 18, 575-583.

Viegas, D., Reis, R., Cruz, M., Viegas, M., 2004. Calibração do Sistema Canadiano de Perigo de Incêndio para Aplicação em Portugal. Silva Lusitana 12, 77-93.

Vega-García, C., Chuvieco, E., 2006. Applying local measures of spatial heterogeneity to landsat-TM images for predicting wildfire occurrence in Mediterranean landscapes. Landscape Ecol. 21, 595-605.

Weissteiner, C.J., Boschetti, M., Böttcher, K., Carrara, P., Bordogna, G., Brivio, P.A., 2011 Spatial explicit assessment of rural land abandonment in the Mediterranean area. Global Planet. Change 79, 20-36. 